\title{
Acquisition of Arabic Language Based on Stephen Krashen's Theory in the Arabic Camp Activities
}

\author{
Suci Ramadhanti Febriani \\ UIN Maulana Malik Ibrahim Malang \\ Email: Suciramadhantifebriani11@gmail.com
}

\begin{abstract}
The determining factors for a person's success in language vary widely. One of them is the acquisition of a person's language which is a source of skill in producing the language itself. There is often a contradiction between the terms language acquisition and language learning. Psycholinguistics experts view that language acquisition only occurs for the first language, but this is different from Stephen Khrasen who stated that language acquisition can be obtained for foreign languages. On this basis, researchers studied the implementation of foreign language acquisition at MAN 1 Padang during the Arabic Camp activity, based on Stephen Khrasen's theory. Researchers used a qualitative approach with a case study research design. Data collection includes observation, interviews and documentation with data analysis techniques using data triangulation. The results showed that the acquisition of a second language was influenced by good input and processes such as the all-day language environment and good monitoring processes from the tutors. All of this is in accordance with Stephen Khrasen's theory which will provide maximum output in producing Arabic like native speakers even though it is still in a simple sentence formation system in the Camp environment.
\end{abstract}

\section{Keywords: Arabic Camp, Language Acquisition, Stephen Khrasen}

Abstrak
Faktor penentu keberhasilan seseorang dalam berbahasa sangat bervariasi. Salah
satunya adalah pemerolehan bahasa seseorang yang menjadi sumber dalam
keterampilan memproduksi bahasa itu sendiri. Sering terjadi kontradiksi antara
istilah pemerolehan bahasa dan pembelajaran bahasa. Para pakar psikolinguistik
memandang bahwa pemerolehan bahasa hanya terjadi untuk bahasa pertama,
tetapi hal ini berbeda dengan Stephen Khrasen yang mengungkapkan bahwa
pemerolehan bahasa bisa didapatkan untuk bahasa asing. Atas dasar tersebut,
peneliti mengkaji implementasi pemerolehan bahasa asing di MAN 1 Padang
saat proses kegiatan Arabic Camp, berdasarkan teori Stephen Khrasen. Peneliti
menggunakan pendekatan kualitatif dengan desain penelitian studi kasus.
Pengumpulan data meliputi observasi, wawancara dan dokumentasi dengan
teknik analisis data menggunakan triangulasi data. Hasil penelitian


menunjukkan bahwa pemerolehan bahasa kedua dipengaruhi oleh input dan proses yang bagus seperti lingkungan berbahasa sepanjang hari dan proses pemantauan yang baik dari para tutor. Semua ini sesuai dengan teori Stephen Khrasen yang akan memberikan output yang maksimal dalam memproduksi bahasa Arab layaknya penutur asli meski masih dalam tatanan pembentukan kalimat sederhana di lingkungan Camp.

Kata Kuci: Arabic Camp, Pemerolehan Bahasa , Stephen Khrasen

\section{ملخص}

تختلف العوامل المحددة لنجاح الشخص في اللغة اختلافا متنوعا. أحسها اكتساب لغة الشخص التي هي مصدر المهارة في إنتاج اللغة نفسها. وغالبًا وقع التناقض بين مصطلحي اكتساب اللغـة وتعلم اللغة. ويرى خبراء علم اللغة النفسي أن اكتساب اللغـة يحدث للغة الأولى فحسب، وهذا يختلف بستيفن خراسن الذي ذكر أن اكتساب اللغة يمكن الحصول عليه للغات أجنبية. و بهذه الفكرة، درس الباحثون تنفيذ اكتساب اللغة الأجنبية في 1 Padang أثناء نشاط المخيم العربي، بناءً على نظرية ستيفن خراسن. استخدمت الباحثّة نهجًا نوعيًا مع تصيميم بحث لدراسة الحالة. يشمل جمع البيانات المراقبة والمقابلات والتوثيق باستخدام تقنيات تحليل البيانات باستخدام تثليث البيانات. فالنتائج من هذا البحث العلمى أن اكتساب لغة ثانية قد تأثر بمدخلات وعمليات جيدة مثل بيئة اللغة طوال اليوم وعمليات المراقبة الجيدة من المعلمين. كل هذا يتوافق بنظرية ستيفن خراسن التي ستوفر أقصى قدر من الإنتاج في إنتاج اللغة العربية مثل المتحدثين الأصليين على الرغم من أنها لا تزال في نظام تكوين جملة بسيط في بيئة

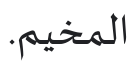

\section{الكلمة الرئيسية: مخيم عربي، اكتساب اللغة، ستيفن خراسن}

\section{Introduction}

The process of acquiring language is very important, which aims at mastering a foreign language or language of achievement. This has become an interesting study that has led to many innovations and rapid developments in language acquisition and finally that a person is able to produce the intended language properly and correctly. As the statement 
that the environment is a determining factor in language acquisition. ${ }^{1}$ Not only that, environmental support can shape students to be skilled at producing the right language. ${ }^{2}$

The acquisition of a second language is actually a result of the interaction process between the special tools that handle language and is the innate potential of every human being. In a neurological perspective, language activities are in a certain part of the human brain, namely the left brain deals with speech production and the right brain is involved in reading activities and the relevance of psychomotor movements to language memory. Thus, learning activities largely determine the success of students who are cognitive (part of the left brain). However, this is always a contradiction with other psychologists who do not provide opportunities for the concept of second language acquisition.

As some psycholinguistics challenge the claim that language acquisition can be done by adults. ${ }^{3}$ Like Choamsky who rejected that statement. ${ }^{4}$ However, Krashen gave statements for the theory of language acquisition and considers that the acquisition of language can occur by adults. ${ }^{5}$ Language acquisition can be applied to second languages with comprehensive environmental support.

As well as the role of a good environment can shape behavior and appropriate responses. This is in line with Skinner's statement that humans move and do activities cannot be separated from the environment with the stimulus-response scheme from the surrounding environment. As the schematic is illustrated below.

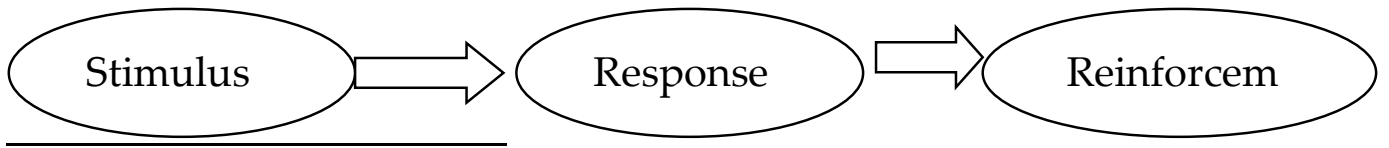

${ }^{1}$ Qiang Huang, "Learners' Perceptions of Blended Learning and the Roles and Interaction of F2f and Online Learning.," ORTESOL Journal 33, no. 2013 (2016). Pg. 14-33.

2 Suci Ramadhanti Febriani, Wildana Wargadinata, and Faisal Mahmoud Adam, "Design of Arabic Learning for Senior High School in the 21 St Century" 12, no. 1 (2020): 1-21, https://doi.org/10.24042/albayan.v12i1.5886.

${ }^{3}$ Alif Cahya Setiyadi and Mohammad Syam'un Salim, "Pemerolehan Bahasa Kedua Menurut Stephen Krashen," Jurnal At-Ta'dib 8, no. 2 (2013).

4 Pamela J. Stewart and Andrew J. Strathern, "Breaking the Frames: Anthropological Conundrums," Breaking the Frames: Anthropological Conundrums, 2016. Pg. 1-104. https://doi.org/10.1007/978-3-319-47127-3.

${ }^{5}$ Stephen D. Krashen, "Formal and Informal Linguistic Environments in Language Acquisition and Language Learning," TESOL Quarterly 10, no. 2 (1976). Pg. 157. https://doi.org/10.2307/3585637. 


\section{Figure 1. Skinner's Theory.}

From Figure 1 it is known that the response stimulus adopted by Skinner's theory is a change in behavior as a result of the first experience. ${ }^{6}$ Experience is the result of capturing human sensory responses that can influence behavior. ${ }^{7}$ The response process carried out to the environment is a learning effort that results.

The role of the environment is very important in shaping one's language acquisition or language production. As outdoor activities or nonformal activities have a special attraction for learners. ${ }^{8}$ They can take the experience through direct interaction and practice the production of the language they get. ${ }^{9}$ This activity can increase student creativity and feel relaxed when learning takes place. ${ }^{10}$

The positive impact during outdoor learning is being able to develop social attitudes, student character, and critical thinking power. As the outdoor learning process is suitable for children and adults. This will lead the brain to relax and add insight naturally without being pressured by the demands of what to do. Therefore, language learning is like language acquisition even though it is supported by a good language environment. ${ }^{11}$ As stated, the environment is able to shape students naturally.

The process of acquiring language can be carried out in second languages. Through Krashen's theory which describes several language

${ }^{6}$ Skinner, Verbal Behavior. (Harvard University, 1948).

7 Zaini Rifnon, "Studi Atas Pemikiran B.F. Skinner Tentang Belajar," TERAMPIL Jurnal Pendidikan Dan Pembelajaran Dasar 1, no. 1 (2014). Pg. 118-129.

${ }^{8}$ Nur Salina Ismail and Izah Mohd Tahir, "English Camp Activities: A Strategy to Enhance Students' English Proficiency," Studies in Literature and Language 2, no. 3 (2011). Pg. 61-72. https://doi.org/10.3968/j.sll.1923156320110203.009.

${ }_{9}$ Chun Lai, "Modeling Teachers' Influence on Learners' Self-Directed Use of Technology for Language Learning Outside the Classroom," Computers and Education 82 (2015). Pg. 74-83. https://doi.org/10.1016/j.compedu.2014.11.005.

10 Yixuan Tong et al., "Children and Structured Holiday Camping: Processes and Perceived Outcomes," Tourism Management Perspectives 35, no. February (2020). https://doi.org/10.1016/j.tmp.2020.100706.

${ }^{11}$ Ninger Zhou and Aman Yadav, "Effects of Multimedia Story Reading and Questioning on Preschoolers' Vocabulary Learning, Story Comprehension and Reading Engagement," Educational Technology Research and Development 65, no. 6 (2017). Pg. 15231545, https://doi.org/10.1007/s11423-017-9533-2. 
acquisition hypotheses which can be described as follows; the acquisition and learning hypothesis, the natural sequence hypothesis, monitor hypothesis, the affective filter hypothesis. ${ }^{12}$ Through these steps, its can be formed through Arabic Camp activities. This activity creates an informal language environment, so it can suppress students' anxiety in acquiring language and suppress anxiety in terms of producing foreign languages.

Camping activities are activities that can be done outdoors. ${ }^{13}$ As one of the outdoor programs that is currently developing is a camping activity that can encourage students' interest in learning in practicing foreign languages. This activity is also one of the MAN 1 Padang programs which are held as an effort to introduce students to academics at Madrasahs. The Arabic Camp program is implemented with the assistance of teachers and a team of tutors from UIN Imam Bonjol Padang.

Several previous studies have examined language acquisition such as; descriptive analysis of second language acquisition ${ }^{14}$, criticism of Stephen Krashen's theory ${ }^{15}$, language formation through Camping and second language acquisition in Higher Education. ${ }^{16}$ On that basis, a fundamental study is still needed related to the acquisition of a second language which is packaged through the Arabic Camp activities at MAN 1 Padang City. So it aims to see the process of acquiring Arabic with environmental techniques based on kamping. On that basis, the researcher wanted to study and analyze the language acquisition process according to Stephen Krashen with the concept of Arabic Camp in MAN 1 Padang.

\section{Method}

This study utilized a descriptive qualitative approach through a case study. Qualitative research aims to analyze language acquisitionbased on

12 Krashen, "Formal and Informal Linguistic Environments in Language Acquisition and Language Learning."

${ }^{13}$ Tong et al., "Children and Structured Holiday Camping: Processes and Perceived Outcomes."

${ }^{14}$ Rendy Pribadi, Zainal Rafli, and Ninuk Lustyantie, "The Influence of Family in Second Language Acquisition in Children Aged 1.5 Years: An Analysis of Monitoring Theory by Krashen" 3, no. 01 (2019). Pg. 22-29.

${ }^{15}$ Wen Lai and Lifang Wei, "A Critical Evaluation of Krashen's Monitor Model," Theory and Practice in Language Studies 9, no. 11 (2019). Pg. 1459. https://doi.org/10.17507/tpls.0911.13.

16 Suci Ramadhanti Bahruddin, Uril, Febriani, "Implementation of Krashen ' s Theory in Language Acquisition Stephen" 13, no. 8 (2020). Pg. 821-31. 
Stephen Krashens's Thepry. This is based on the description of words and language in a specific natural context with various scientific methods. ${ }^{17}$

The data from research subjects were comprehensively scrutinized. The case study research was chosen because of the need to explain and reveal the overall and comprehensive. ${ }^{18}$ The participants came from students, tutors and teachers at MAN 1 Padang. The researcher took random participants in Arabic Camp activities.

The data collection techniques used include interviews, observation, and documentation. Random sampling techniques were used, where each individual had the same chance of being selected as an informant. A random sample to collect data about students' perceptions of Arabic Camp and Language Acquisition based on Stephen Krashens' Theory. Furthermore, the observation was used to gather information on language environment and classroom. Documentation was used to collect information about classroom administration and the learning process from the lesson plans and academic guidance books. The interview aims to explore information related to Language Acquisition and students' perceptions in learning Arabic using Arabic Camp environment.

Data triangulation is one way to check the validity of the data by using factors or something outside the data itself to check the data. The researcher uses this method to compare existing data and when he discovers differences between collected data and documents and observation guidelines. The analysis techniques used were based on triangulation data, where they were collected and described, reduced, and verified. Data collection was carried out in early May to June. The data was then reduced by selecting and sorting the details that support the research and eliminating the uncessary details.

${ }^{17}$ Lexy J Moleong, Metodologi Peneleitian Kualitatif (Rosdakarya Offset, 2007).

${ }^{18}$ Robert K. Yin, "Robert K. Yin Case Study Research Design and Methods, Third Edition, Applied Social Research Methods Series, Vol 5 2002.Pdf," 2003. 
The researcher uses the following steps in the process of analyzing data:

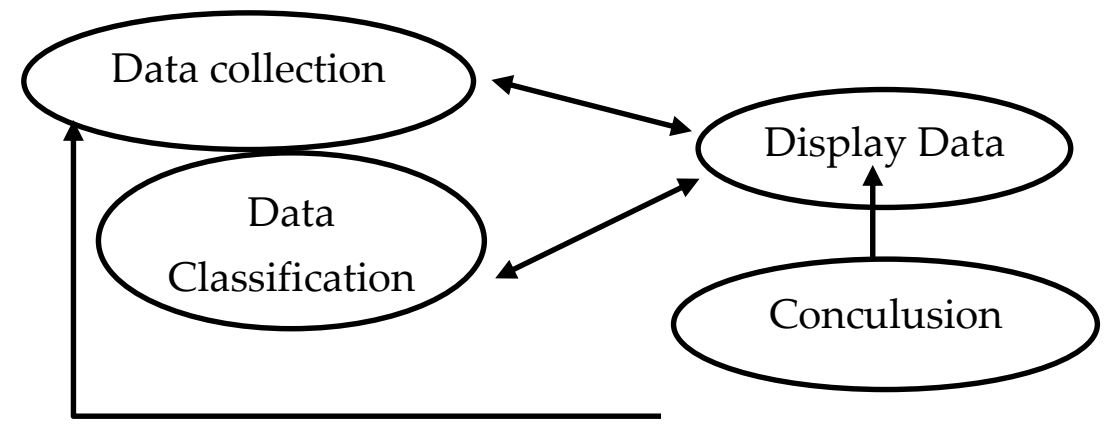

Figure 2. Procedure in analyzing data

Through the figure 2, several steps in analyzing the data are described as follows;

1) Data collection. The researchers collected data from the observation, as the researchers notes the existing activities related to language acquisition in Arabic Camp process. As for the information from the documents, the researchers collects it through lesson plan about teaching the Arabic language in Arabic Camp.

2) Data Classification. In the data classification, the researchers reduced the data related to the case and classified it as encoding. In classifying data, the researchers focused on data related to language acquisition.

3) Display data. The step in which the data is reduced is the data display. Data presentation is the process of presenting and processing it, which includes: the process of identification, classification and organization, and explanation methodically, objectively, and comprehensively, and finally comes the interpretation.

4) Conclusion. The last step is to take deduction. In this step, the researchers concluded the research findings according to the researcher's classifications and according to his interpretations.

\section{Results and Discussion}

Arabic Camp at MAN 1 Padang was held for 7 days. This activity is one of the special programs given at the beginning of the new school year for grade one. In this activity, 300 students took part in Arabic Camp, consisting of majoring in science, social studies and religion. The conditions of Arabic language proficiency in each department are different. There are students who come from Islamic boarding schools, junior high schools and Madrasah Tsanawiyah. 
This activity companion is under the supervision of the Principal and Head of the Arabic Language Education Department of UIN Imam Bonjol Padang. Arabic Camp activities under the guidance of an Arabic teacher at MAN 1 Padang City and 30 tutors from Arabic Language Education students at UIN Imam Bonjol Padang. The Arabic language skills of tutors vary. Based on the results of the Test of Arabic Foreign Language, the Arabic Camp tutor coordinator has a minimum score of 500. Then, he guides other tutor members.

Arabic Camp activities can be seen in the following procedure.

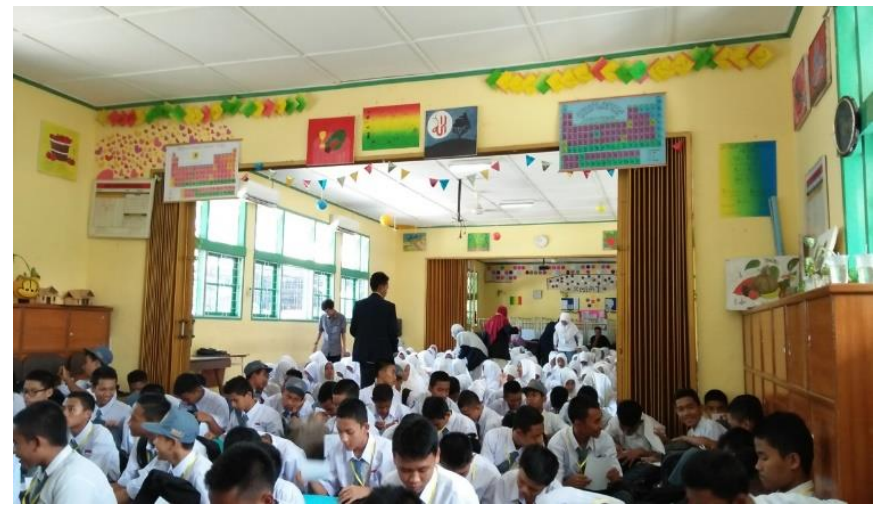

Figure 3. Arabic Camp Activity Procedure

The procedure for the activities carried out can be seen in Figure 3. In the first stage, students fill out a questionnaire of interest for the activities to be followed. There are four different program options offered, namely Calligraphy, Arabic Poetry, Speech and Drama. After students complete the specialization questionnaire, teachers and tutors classify students' interests into three different levels, namely elementary, middle and high levels. students who fall into the basic category are students who have never previously studied Arabic such as students from public junior high schools, while students who have intermediate level abilities are students from Madrasah Tsanawiyah who have studied Arabic with medium intensity, while students who in the high level category, namely students who come from Islamic boarding schools who have studied Arabic intensively.

The existence of student mapping is useful for teachers and tutors to improve the quality of student skills on an ongoing basis. ${ }^{19}$ As it is said that

19 Janniarni Toha Safutri, Suci Ramadhanti Febriani, and Danial Hilmi, "Improvement Of Arabic Language Tearcher Competency Based On Multiple Intelligences," Lughawiyyah 2, no. 1 (2020). 
the separation of student abilities aims to make it easier for teachers to choose learning strategies and provide guidance to students. ${ }^{20}$ Meanwhile, when learning is at a low level, teachers and tutors provide more material, while for middle and high levels, teachers and tutors provide more applicable skills and provide intense assistance in improving language productive skills, namely speaking and writing. As stated, the pedagogical competence of teachers who are able to provide assistance is very influential in the success of learning.

The language acquisition process during the Arabic Camp activity can be seen through the following explanation.

First, the hypothesis of language learning and acquisition. Language acquisition and language learning are two distinct terms. Language acquisition is obtained naturally and without a conscious process from the speaker, while the language learning process is an activity that is carried out consciously with structured and systematic guidance with a predetermined curriculum. Through the Arabic Camp activities, these two activities are carried out simultaneously.

The formulation of the target language rules is carried out and internalized unconsciously. Thus, the language acquisition process takes place naturally without any manipulative conditions. This is almost the same as the process of acquiring language in children. In this case, the priority for obtaining the first language is the content of the message, not the linguistic form such as the existing grammatical elements.

Through this, Arabic Camp activities provide an area for students to produce language in the form of drama exercises, daily conversations and express discourse in simple forms. Even though there are still mistakes and mistakes, they occur naturally.

The tutors provide learning at the beginning of the meeting, then Arabic production practice is carried out after students receive material that has been arranged through modules. The Arabic learning process after Arabic Camp should be followed up as well as efforts to develop student skills and develop effective modules. One of the modules implemented is as follows.

${ }^{20}$ Khairun Nisaa Mohd et al., "Teaching Arabic Language to Malaysian University Students Using Education Technologies Based on Education 4.0 Principles," International Invention, Innovative \& Creative (InIIC) Conference, 2019, no. November (2019). Pg. 38-51. 


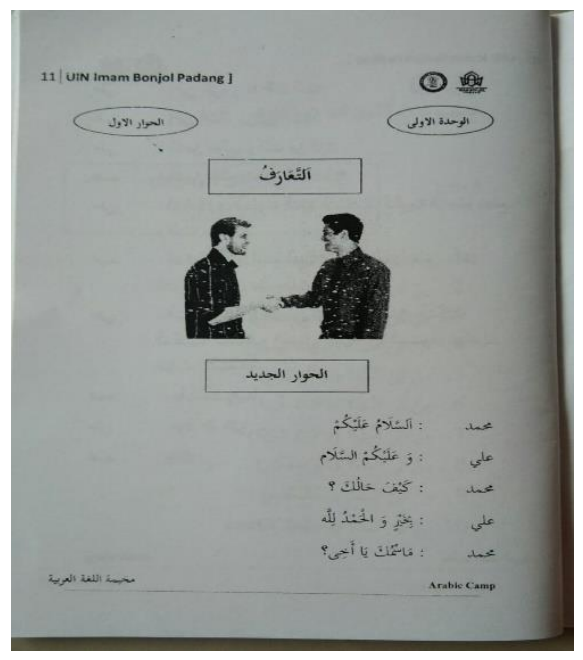

Figure 4 shows one of the conversation materials at the first meeting. The use of modules also makes it easier for students to obtain the material presented. ${ }^{21}$ However, design considerations also need to be considered carefully. One of the informants said that:

The material presented in the module is well organized and contains pictures and vocabulary that can be used in everyday life. However, the lack of a coloring design is one of the students' boredom (Interview Ih).

Each material is contained in the modules provided by the tutors. At the end of the activity, students can display creations with drama designs in which there are performances of poetry, speeches, calligraphy with roleplaying packaging. Through the performances that are served, students can develop their creations. One of the informants said the lack of time effectiveness in this activity was a suggestion in itself.

Through this module, students can learn the language. The strategy developed is direct learning. Then the process of acquiring language is obtained through daily question and answer activities with peers. This encourages students to use vocabulary in the form of simple sentences.

Second, the natural hypothesis process. In the process of natural hypotheses, Krashen reveals that the process of consciously selecting the rules of the second language - rational and cognitive and takes place in a formally manipulative artificial environment. in this case, the sequence of

${ }^{21}$ Nesreen Alhmadi, "Essential Skills in Arabic: From Intermediate to Advanced," British Journal of Middle Eastern Studies 46, no. 1 (2019). Pg. 205-207, https://doi.org/10.1080/13530194.2018.1507435. 
grammatical mastery starts with simple things. Just like mastery in Arabic, starting with easy grammar. Through Arabic Camp activities, the tutor provides a simple conversation concept at the beginning of the meeting. After that, the introduction of grammar and its use in daily activities is one of the main stresses.

Arabic Camp activities emphasize everything from easier learning to graded learning to more difficult learning. This can be illustrated when students acquire language starting from sound phonology, vocabulary then in syntactic form. Through this natural hypothesis, students can unconsciously use and acquire language ranging from simple levels to more complex sentences. ${ }^{22}$

Third, the process of monitoring hypotheses. According to Krashen, language acquisition results in a creative construction system which is a naturally acquired competency. According to him, learning activities do not help much in editing, correcting and correcting the grammar of speech and not determining fluency and language proficiency. As with the Arabic Camp activities, the fluency process is achieved through habitual speaking and language production. The monitoring process takes the form of checking for errors and errors in language production. On that basis, monitoring activities are an effort to provide grammatical justification, in addition to paying attention to the content of the messages being spoken.

Monitoring activities are carried out by tutors and peers in the Arabic Camp environment. In addition, teachers also participate in supervising this activity. The role of monitoring is useful for correcting mistakes and mistakes of students in producing language. ${ }^{23}$ This is something that is normal in the learning process and in the process of speaking a foreign language.

The acquisition of Arabic is obtained through the awareness of students in understanding the readings and voices played by the teacher through a tape recorder and direct voice. Through teacher guidance, language speech errors can be corrected through peer reviews or corrections made by the teacher. Through this correction, students can correct their mistakes when making speech errors in terms of letters or sentences. As explained, humans actually have an effective filter to be

${ }^{22}$ Krashen, "Formal and Informal Linguistic Environments in Language Acquisition and Language Learning."

${ }^{23}$ (Bahruddin \& Febriani; 2020) 
motivated in learning language. This effective filter will be able to encourage students to accept and produce language well.

Fourth, the affective filter process. Affection filtering will be loose if second language learners are calm, happy, not nervous or afraid so that the information obtained can easily enter the brain without any formal pressure. This will have an impact when students feel afraid, anxious, tired and embarrassed, the affective filter will be closed tightly so that the input received cannot be said that the acquisition of a second language did not work well.

This process is very developed in Arabic Camp activities. As is known during the learning process, students generally experience high anxiety when they are unable to pronounce the foreign language being studied. However, in Arabic Camp activities, the affective filter process is going well. This is known through the level of anxiety and naturalization in students' language. ${ }^{24}$ The outdoor learning process is also a factor that affects students' affective filters. ${ }^{25}$ They can produce language that is more relaxed than the formal learning process in class.

\section{Conclussion}

The process of language acquisition based on Stephen Krashen's theory can be done through outdoor activities such as Arabic Camp. This activity indicates the acquisition of language acquired by adults. As the process of acquiring language is carried out naturally with the support of adequate learning tools such as modu and tutors who are competent in the field of Arabic. As one of the outputs produced is when students are able to produce simple sentences that are used in daily activities. The speaking process carried out by the Arabic Camp participants was carried out unconsciously without worrying about language production. With this, the monitoring process can run well even though the Arabic Camp activities are limited. This study recommends further research to assess the effectiveness of Arabic Camp activities in a different perspective category or to develop this research method into a more complex method.

24 Charles Kivunja, "Innovative Methodologies for 21st Century Learning, Teaching and Assessment: A Convenience Sampling Investigation into the Use of Social Media Technologies in Higher Education," International Journal of Higher Education 4, no. 2 (2015). Hal. 1-26, https://doi.org/10.5430/ijhe.v4n2p1.

25 Arifka Mahmudi et al., "CLASSROOM MANAGEMENT AND ARABIC LEARNING PROCESS BASED ON MULTIPLE Arabiyât” 6, no. 2 (2019). Pg. 222-237. 


\section{References}

Alhmadi, Nesreen. "Essential Skills in Arabic: From Intermediate to Advanced." British Journal of Middle Eastern Studies 46, no. 1 (2019). https://doi.org/10.1080/13530194.2018.1507435.

Alif Cahya Setiyadi, and Mohammad Syam'un Salim. "Pemerolehan Bahasa Kedua Menurut Stephen Krashen." Jurnal At-Ta'dib 8, no. 2 (2013).

Bahruddin, Uril, Febriani, Suci Ramadhanti. "Implementation of Krashen 's Theory in Language Acquisition Stephen" 13, no. 8 (2020).

Febriani, Suci Ramadhanti, Wildana Wargadinata, and Faisal Mahmoud Adam. "Design of Arabic Learning for Senior High School in the 21 St Century" 12, no. 1 (2020). https://doi.org/10.24042/albayan.v12i1.5886.

Huang, Qiang. "Learners' Perceptions of Blended Learning and the Roles and Interaction of F2f and Online Learning." ORTESOL Journal 33, no. 2013 (2016).

Ismail, Nur Salina, and Izah Mohd Tahir. "English Camp Activities: A Strategy to Enhance Students' English Proficiency." Studies in Literature and Language 2, no. 3 (2011). https://doi.org/10.3968/j.sll.1923156320110203.009.

Kivunja, Charles. "Innovative Methodologies for 21st Century Learning, Teaching and Assessment: A Convenience Sampling Investigation into the Use of Social Media Technologies in Higher Education." International Journal of Higher Education 4, no. 2 (2015). https://doi.org/10.5430/ijhe.v4n2p1.

Krashen, Stephen D. "Formal and Informal Linguistic Environments in Language Acquisition and Language Learning." TESOL Quarterly 10, no. 2 (1976). https://doi.org/10.2307/3585637.

Lai, Chun. "Modeling Teachers' Influence on Learners' Self-Directed Use of Technology for Language Learning Outside the Classroom." Computers and Education 82 (2015). https://doi.org/10.1016/j.compedu.2014.11.005.

Lai, Wen, and Lifang Wei. "A Critical Evaluation of Krashen's Monitor Model." Theory and Practice in Language Studies 9, no. 11 (2019). https://doi.org/10.17507/tpls.0911.13.

Lexy J Moleong. Metodologi Peneleitian Kualitatif. Rosdakarya Offset, 2007. Mahmudi, Arifka, Suci Ramadhanti Febriani, Maidatul Hasanah, Zakiyah 
Arifa, Universitas Islam, Negeri Maulana, Malik Ibrahim, Kota Malang, and Jawa Timur. "CLASSROOM MANAGEMENT AND ARABIC LEARNING PROCESS BASED ON MULTIPLE Arabiyât" 6, no. 2 (2019): 222-37.

Mohd, Khairun Nisaa, Airil Haimi Mohd Adnan, Ahmad Arifuddin Yusof, Muhammad Khairul Ahmad, and Muhammad Anwar Mohd Kamal. "Teaching Arabic Language to Malaysian University Students Using Education Technologies Based on Education 4.0 Principles." International Invention, Innovative \& Creative (InIIC) Conference, 2019, no. November (2019).

Pribadi, Rendy, Zainal Rafli, and Ninuk Lustyantie. "The Influence of Family in Second Language Acquisition in Children Aged 1.5 Years: An Analysis of Monitoring Theory by Krashen" 3, no. 01 (2019).

Rifnon, Zaini. "Studi Atas Pemikiran B.F. Skinner Tentang Belajar." TERAMPIL Jurnal Pendidikan Dan Pembelajaran Dasar 1, no. 1 (2014).

Safutri, Janniarni Toha, Suci Ramadhanti Febriani, and Danial Hilmi. "Improvement Of Arabic Language Tearcher Competency Based On Multiple Intelligences." Lughawiyyah 2, no. 1 (2020).

Skinner. 1948. Verbal Behavior. Harvard: Harvard University.

Stewart, Pamela J., and Andrew J. Strathern. "Breaking the Frames: Anthropological Conundrums." Breaking the Frames: Anthropological Conundrums, 2016. https://doi.org/10.1007/978-3319-47127-3.

Tong, Yixuan, Mao Ying Wu, Philip L. Pearce, Junqing Zhai, and Haili Shen. "Children and Structured Holiday Camping: Processes and Perceived Outcomes." Tourism Management Perspectives 35, no. February (2020). https://doi.org/10.1016/j.tmp.2020.100706.

Yin, Robert K. "Robert K. Yin Case Study Research Design and Methods, Third Edition, Applied Social Research Methods Series, Vol 5 2002.Pdf," 2003.

Zhou, Ninger, and Aman Yadav. "Effects of Multimedia Story Reading and Questioning on Preschoolers' Vocabulary Learning, Story Comprehension and Reading Engagement." Educational Technology Research and Development 65, no. 6 (2017). https://doi.org/10.1007/s11423-017-9533-2. 